\title{
Discussion on Innovation of English Translation Teaching Methods in Colleges
}

\author{
Yonghong $\mathrm{Wu}$ \\ Xi'an University, School of Foreign Studies, 710065
}

Keywords: Colleges; English Translation; Teaching; Innovation

\begin{abstract}
Globalization and integration are developmental trends of the world nowadays. As an international vehicular language, English plays a non-replaceable role among the people in different regions and nations and with different cultural background. Along with social development and progress, the demand for English translation talents is nearly in geometric growth. However, due to the influence of the social, political and economic environments, English translation teaching in colleges is up against many problems at present, which have gradually become the focus concerned by the whole English translation circle. Currently, many colleges offer the course of English translation. But, an urgent practical problem faced by each educator is how to do well English translation teaching and cultivate outstanding professionals of English translation.

Economic integration and globalization are main developmental trends of the world today. Along with continual deepening of global communication, more and more posts need professional translators. Meanwhile, each post has higher and higher requirements for comprehensive linguistic competence of translation talents. In case the requirements of each college for students' English competence are simply rested on grasping grammar, accumulating vocabulary and coping with CET4 and CET6, the talents from such a system cannot meet economic and social development in our country obviously.

Undergraduates should pay much attention on cultivation of comprehensive English competence, of which the important part is cultivation of translation competence. At present, English translation is characterized in huge information content, wide varieties, broad coverage, quick knowledge updating and so on. In order to match up to these characteristics, all colleges offer different levels of English translation courses to cultivate and figure professional translators and interpreters, who can meet different demands.

In the new historical period of social development, we have proposed new and higher requirements for translation teaching and set new expectation for instructional objectives. Under the new circumstance, in order to cultivate qualified talents of modernization, we should change traditional conception for translation teaching, grasp basic translation theories and skills and try our best to build up certain translation diathesis and competence of the students so that they can understand translation strategies based on experience and guidance and have a well-knit adaptability.

At present, there is not a systematic teaching method for English translation teaching in China. The lectures of the teachers present such abuses as varying contents, different methods, multiple means and so on, so that the English translation teaching is blind and random. Objectively speaking, the objective of English translation teaching determines the results of English translation courses to a large extent and different teaching objectives result in different teaching results by the nature of the case. In English translation teaching, some teachers aim to cultivating linguistic competence of the students and focusing on quality-oriented education; some teachers aims to improving translation skills of the students and trying to cultivate self-study and self-improvement capabilities in practice; others pay attention to cultural edification and let students to fully understand the intrinsic values of different cultural systems to cultivate the students' language cognition ability rooting in the culture system.

English Translation is a unique science. Accurately speaking, it is one of many language activities and a practice that a language is objectively transformed into another language orally or in writing. Unlike pure language teaching, English translation teaching needs special translation training.
\end{abstract}




\section{Objective of English Translation Teaching in Colleges}

The real objective of English translation teaching in colleges should not rest on academic level but on application. Main objective of English translation teaching is to cultivate the students into practical talents for the society rather than bookworms, who are only wise to several theories but find themselves in the mire in handling actual problems. Practical English translation is different from that in theory or imagination. It requires us to set out from the practice of English translation and complete translation tasks according to the required time, quantity and quality. At present, the English educators of many colleges are following this objective, have carried out continual searching and audacious innovation in practice of English translation teaching and have obtained many invigorating innovations in teaching methods.

\section{Importance of English Translation Teaching in Colleges}

Due to historical and systematic reasons, English translation was not thought much of for a long period. In the context of advocating quality-oriented education, it may be evident that getting done with English translation teaching is an important component of strengthening quality-oriented English education.

As an international language, English plays a quite important role in international contacts. In China, many colleges lay stress on cultivating English translation competence of the students. The students are directed to grasp relevant translation contents by the method that English translation teachers induct basic theoretical knowledge, translation skills and so on in class. These contents establish a quite important basis for students to carry on relevant work in the future. However, from the aspect of current social demand, our translation teaching is relatively laggard. Since the reform and opening, China has made considerable progresses in economy, society, culture and so on, international cooperation has spread out all-roundly and more and more international friends have come to China for traveling, investment, lecturing and so on, but there is still a large gap for good translation talents. It is obvious to all that translation is a bridge of Sino-foreign exchange. So, getting done with cultivation of translation talents not only relates to the advance of overall quality-oriented education strategy in colleges but also has a certain effect on the advance of Chinese modernization construction.

\section{Problems in English Translation Teaching of Colleges at Present}

China has the largest group of English learners and also makes great investment in English learning. All colleges pay much attention to cultivation of students' English competence and have obtained desirable achievements. English competence of the students has been improved generally. However, as an important component of college English teaching, translation teaching is also confronted with some problems during its development, which severely limits development of students' English competence and construction of the English teaching system.

\section{English Translation Teaching is not Thought much of Sufficiently.}

For a long time, many people have been ignoring the importance of English translation teaching and getting into cognition error areas in some or other way. In our country, some people publicly expressed there was no translation theory and translation teaching depended on practice without any need for theory; some people thought translation was a representation of soul and understanding, translators' ability was congenital and many translators translated many classic works without systematic translation training. Therefore, translation should not be taught or learnt and translation teaching was dispensable; some people thought that translation was only a simple peer-to-peer conversion between languages, the ambit of translation could be achieved by inputting sufficient linguistic data, having abundant vocabulary and considerable grammar accumulation and using several dictionaries. So, there was no need to take time to learn translation knowledge system and join in special translation training. 
At present, the colleges in some regions do not offer sufficient English translation courses. For example, in some colleges, only $1 \mathrm{~h} \sim 2 \mathrm{~h}$ translation courses were offered for English majors and few translation course is provided in Public English Course. In some places, the education department and the teaching management organizations of the colleges have no regard for translation teaching, so that the students do not adequately make account of this course subjectively. Quite a good deal of students also think that grammar, vocabulary and learning / speaking are foremost in English learning, while translation is nothing but a part of reading comprehension and can be done with only a dictionary. Therefore, the students do not aspire after translation accuracy, which is quite disadvantageous for training the students' translation competence.

\section{Influence of Negative Factors in Domestic Social, Economic and Political Environment}

From the aspect of quantity, China is a big translation country, but far from a powerful translation country. Many top-end translations are faced with an awkward circumstance of no qualified translator. Shoddy and debased translation authors are flooding in the market. As translation quality decreases, the translation and publishing worlds still go further for economic benefit, even crazily. All these have a strong impact on the reputation and image of the translation world. In turn, such a translation environment directly influences the development of translation education career. Utilitarian and "snack" translation education can be found everywhere and many famous scholars are indulges in it, impatiently and impetuously. The college is not a piece of Pure Land and is impacted by such a thought and conflict of interest, which has severely disturbed sound and orderly development of to a certain extent.

Teaching Materials are Lagged and their Contents are Single and on the Way out.

English teaching materials are lagged. At present, English translation textbooks used by many colleges are relatively on the way out and their contents and forms lose contact with social development and are even antipathetic. Although some colleges use the textbooks launched out in recent years, there is nothing new in their contents. These textbooks are short of a systematic and scientific system and difficult for the students for drawing inferences about other cases from one instance. As language changes with each passing day and new word and expression are produced every day, the textbooks used in English translation teaching should advance with the times.

\section{The Teachers give Directional Misguide.}

English translation teaching should be under the direction of translation theories. But, there are lots of translation theories, which should be selected according to the personal conditions of the students and the talent training objective of the college. Translation practice is subject to the effect of translation theories, which determine the clew of the translators macroscopically. We should use theoretical knowledge to guide the students' translation from the macroscopic level and do not restrict the students in details, for fear that they may hesitate to move forward.

\section{Cultural Factors are not Sufficiently Introduced in Teaching.}

Any language is impossibly isolated. Language and culture are always an indivisible unity. Many scholars learnt language firstly from their understanding for the culture. A predominant problem in English translation teaching of colleges is that English cultural teaching is not introduced sufficiently. As an organic component of culture, language is good for nothing without the culture. It is appreciable that many teachers put stress on improve students by skills and theories during current English translation teaching but do not give sufficient cultural cultivation for them, and even some teachers think that it is unnecessary to introduce cultural factors in translation teaching.

\section{Research on Innovation of English Translation Teaching Methods in Colleges}

It is believed by the author that we should mainly strengthen the following aspects for innovation and breakthrough in English translation teaching methods in colleges: 


\section{Improve the Understanding of Students for the Importance of English Translation}

As the audience, the attitude of students to English translation directly determines their learning interest and enthusiasm. At the beginning of the course, the teacher should scientifically and correctly state the importance of English translation in the current social development to the students, enabling them to briefly learn about the teaching purpose and subject importance of English translation. In the subsequent teaching practice, the teacher should combine the teaching contents and teaching methods with the current social development pace organically, attracting the learning interest of the students with new teaching contents and original teaching methods and making them realize that English translation is applied everywhere in the modern life and have clear and deep understanding about the importance of English translation unconsciously.

\section{Strengthen the Accumulation of Practice}

As the organizer and implementer of class teaching, the teacher should try to strengthen the teaching practice of the students as far as possible, provide the students with real translation material or simulate translation situation close to reality and make them feel being personally on the scene as far as possible, learning from doing. Continuously improve the linguistic analysis and application ability of the students through practice, improving the students' ability of adapting to the changing circumstance. In this way, it is very good for the accumulation of the students' translation skills. The teacher should make the students realize the importance of practical ability cultivation, motivating the motivation and activity of the students.

\section{English Translation Teaching Methods should be Innovated Continuously}

In English translation teaching, we should renew the teaching method continuously. The traditional teaching method of chalk and blackboard as well as the teacher's filling and cramming has been far from the development of informatization. With the wide popularization of Wechat and network at present, as the main force of scientific products popularization, the students are greatly interested in the changing technologies, and if we are able to combine our teaching methods with the advanced technology, it must resonate with the students and greatly improve the teaching effect. As the representative of new technique development, the depth and breadth of influence of the network on our life are increasing day by day; how to make English translation teaching networked and informatized is a question requiring each English translation educator to think about carefully not to avoid.

In addition, the application of information technology can increase the information amount in translation teaching and improve the learning interest of the students in English translation classes. The teacher can obtain a large amount of information resources by utilizing the network and establish multimedia teaching material database according to different information classification, making them search for the required information quickly in the information base. As for those interested in literature, the teacher can provide them with literature materials for translation practice; as for those interested in technology, the teacher can make them translate the material about technology, which is good for carrying out individualized teaching. Furthermore, applying information technology in English translation teaching is also good for strengthening the interactivity of translation teaching, making students communicate with the teacher timely if they encounter any question.

\section{Strengthen the Teachers Team Construction of English Translation}

In recent years, the degree of emphasis on English translation in many colleges has been improved greatly compared with that in the past. As for teacher allocation, many colleges have tried to pay more attention as far as possible. The successful implementation of English translation teaching is inseparable with the course teacher, and only creating professional teachers team with high level, can it promise to accomplish the teaching target.

\section{Strengthen the Introduction of Cultural Factor in Translation Teaching}

Culture is closely related to the language, which is the carrier of the culture. In the process of transmitting culture, the culture of different nationalities has obvious marks in the form of expressing their language, which makes it difficult for translation. "Translation is the communication between two 
cultures. As for real successful translation, familiar with two cultures is even more important than grasping two languages. It is because that it only has significance in the context of culture.", said Eurgene A. Nida, the American translation theorist. Therefore, translation is to combine the Chinese with the western culture, and it cannot reach the real communication between two languages away from cultural background. It should be paid attention especially in English translation teaching in colleges. The difference between Chinese and western culture exist objectively, therefore, we should consider about the question from the opposite view based on respecting such difference and figure out the meaning of the opposite language, thus, obtain the more objective and correct viewpoint and understanding. Only when we are placing ourselves in the culture of the opposite culture and consider about the question from the point of the opposite foreign culture, can we do the translation work well.

\section{Conclusion}

English translation teaching is a very important component in colleges teaching, and we should pay much attention. The teacher should continuously improve the teaching concept during teaching, adopt scientific and effective teaching method and be brave to carry out creative practice. Only in this way, can we improve and perfect the translation teaching in colleges and cultivate high-quality professional translation talents.

\section{References}

[1] Guo Fuqiang. English Translation Theory and Practice: Ver. 2 [M]. Beijing: China Machine Press, 2008.

[2] Wang Jinbo. Investigation on Translation Teaching Demand for Non-English Major Undergraduates - Take Shanghai Jiaotong University for Example [J]. Foreign Language World, 2009, (5).

[3] Zhang Hairui. Problems in Translation Teaching of College Business English and Countermeasures [J]. Educational Theory and Practice, 2010, 6 (7)

[4] Yu Shuai. Problems in Translation Teaching of College Business English and Countermeasures [J]. Business Perspective. 2014(08)

[5] Lv Ruichang, et al. A Collegiate Course in Chinese-English Translation. Xi'an: Shaanxi People's Publishing House, 2001.5.

[6] Cao Shunqing. Chinese Culture. Shanghai: Fudan University Press, 2006.8.

[7] Wu Guanghua. A New Chinese-English Dictionary. Shanghai: Shanghai Jiaotong University Press, 2003.7.

[8] Ping Hong. Reform on Translation Teaching in College English [J]. China University Teaching, 2002, (2).

[9] Gong Ai'hua. Study on Professional English Translation Teaching for Undergraduates in China [J]. Journal of Jiangxi Normal University, 2004, (6).

[10] Yin Yantong, Xu Guangying. Trends of Domestic Translation Teaching Reform in Recent Years [J]. Journal of China University of Petroleum, 2005, (4).

[11] Mu Lei. Study on Translation Teaching in China [M]. Shanghai: Shanghai Foreign Language Education Press, 1999.

[12] Fang Mengzhi. Translation Studies and Practice [M]. Qingdao: Qingdao Publishing House, 2002.

[13] Cai Jigang. Highlight College English Translation Teaching and Improve English Competence of Students [J]. Chinese Translators Journal, 2003,(1) 